\title{
THE RAVILLA GROUP OF THE ORBWEAVER GENUS ERIOPHORA IN NORTH AMERICA (ARANEAE: ARANEIDAE)*
}

\author{
By Herbert W. Levi \\ Museum of Comparative Zoology, Cambridge, Mass. 02 r 38
}

The contradicting synonymies presented in the two recent catalogs of spiders (Roewer, 1942; Bonnet, 1955) reflect the confusion in names and species of Eriophora in the literature. Comstock ( 1940) indicates that specimens of Eriophora have been found as far north as Oregon. Presumably this error can be traced to the use of the George Marx collection by McCook and Keyserling. The Marx collection, housed in the U.S. National Museum, has unreliable locality labels. No recent collections of Eriophora from central and northern California have been seen.

The object of this revision was to find the differences among species of these very large, common orbweavers of the southern United States. The types of the old names were examined in hope of providing the stability and unversality required of animal names. Only adult specimens that $I$ have myself examined were used for mapping ranges. Unfortunately, South American collections of Araneidae in North American museums are unsorted and only a few specimens provided records for the southern limits of the distributions.

Dr. M. H. Robinson of the Smithsonian Tropical Research Institute, Panama Canal Zone, called my attention to his immediate need of an Eriophora revision to make it possible for him to publish his behavior observations. I take this opportunity to thank Dr. J. G. Sheals and Mr. D. Clark for the hospitality extended when I worked at the British Museum (Natural History), and to thank Mr. Clark for numerous favors. Collections were made available by Dr. W. J. Gertsch and Dr. J. A. L. Cooke of the American Museum of Natural History, Dr. M. Grasshoff of the Senckenbergischen Naturforschenden Gesellschaft, Frankfurt, Dr. J. Prószyński, Polish Academy of Sciences, Warsaw, Dr. D. C. Robinson and Mr. C. E. Valerio of the biology department of the University of Costa Rica, San José, Dr. H. V. Weems, Florida State Museum, Gainesville, Prof. H. K. Wallace, University of Florida. Additional specimens were made available by Dr. L. van der Hammen, Natural History

*Manuscript received by the editor December 1, 1970. 


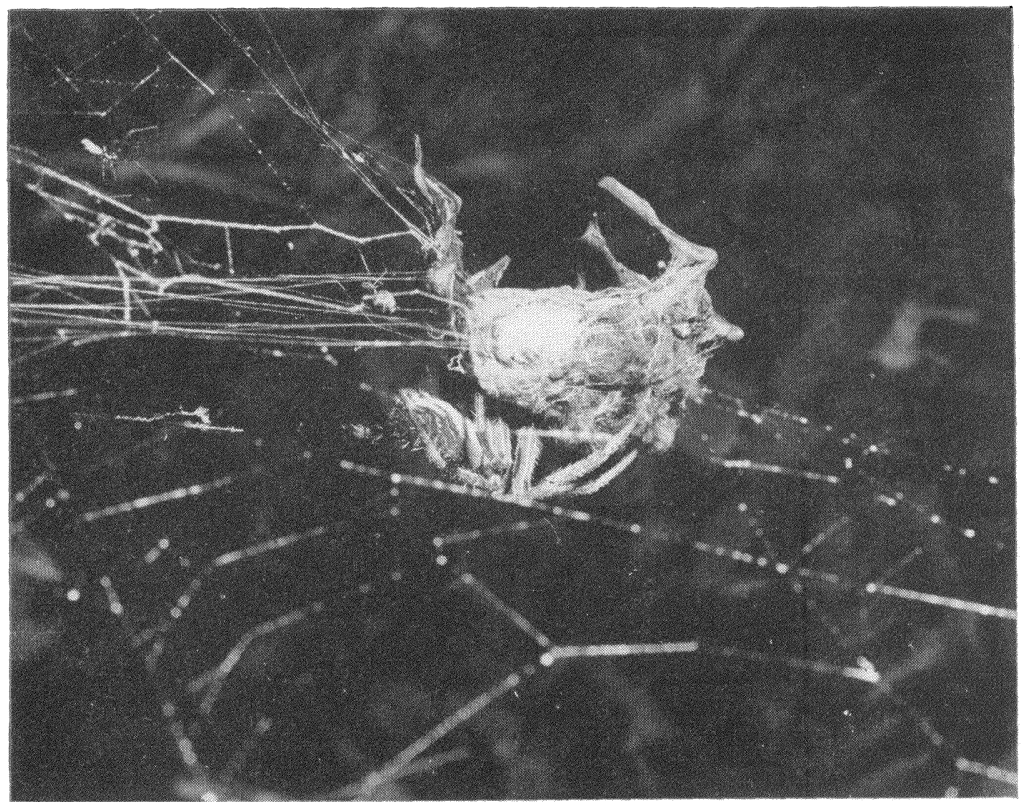

Fig. 1a. Eriophora fuliginea feeding on a bat. On the left are two web parasites belonging to the genus Argyrodes (Theridiidae). Photograph taken in the Panama Canal Zone by Dr. R. Akre.

Museum, Leiden, Dr. M. Moritz, Zoologisches Museum der Humboldt Universität, Berlin, Prof. R. D. Schiapelli and Mrs. B. G. dePikelin, of the Museo Argentino de Ciencias Naturales, Buenos Aires, Mr. D. Bixler and Dr. R. E. Leech. This investigation was supported in part by Public Health Service Research Grant AI-or944 from the National Institute of Allergy and Infectious Diseases, and published with a grant from the Museum of Comparative Zoology.

At present I consider Parawixia a synoym of Eriophora. However, the species customarily included in Parawixia are not included in this paper. They are much less common and most are South American, the most northern ones coming from Mexico. Collections from these areas have not been sufficiently sorted and few specimens are available. The publication of this paper is necessitated by the immediate need for names and means of identification of these common species. 


\section{Eriophora Simon}

Eriophora Simon, 1863, Histoire Naturelle des Araignées, ed. 1, p. 261. New subgenus of Epeira (=Araneus). The type of Eriophora is Epeira ravilla C. L. Koch as designated by F. P.-Cambridge, 1903, Biologia Centrali-Americana, Araneidea, vol. 2, p. 461. The gender is feminine.

All Eriophora species differ from Araneus by having a paramedian apophysis in the palpus (PM in Figs. 2, 4).

The female has the second leg almost the same length as the first (Fig. Ib); the third is always shortest. The median eyes are separated by about their diameter or less. The clypeus width is less than the diameter of the anterior median eyes. The abdomen shape varies from bluntly pointed anteriorly, acutely pointed posteriorly, and widest in the anterior third, to almost spherical (Fig. 32). The posterior of the abdomen is generally high above the spinnerets (Figs. 22-24). There are often posterior or dorsal tubercles on the abdomen: In $E$. ravilla there is one posterior to another; in $E$. edax (Figs. 42-44) there is always one distinct tubercle and often more. The venter has a median black patch (Figs. I6, 3I).

The lateral eyes of males are on a short stalk, the medians on a projection. The small chelicerae are long, attenuated and concave anteriorly, providing space for the large palps. The first coxae of males have a hook on the distal margin (absent in $E$. nephiloides). The second tibiae are modified, most so in $E$. ravilla (Fig. 8), only swollen in $E$. nephiloides. The fourth coxae have a row of transverse macrosetae in $E$. edax (Fig. 48) and thin setae in $E$. nephiloides (Fig. 58). An unusual character is the presence of two strong macrosetae on the fourth trochanter of males (Figs. 7, 48) (except in $E$. nephiloides, which has only some weak setae).

Juvenile specimens of Eustala and Eriophora are often confused.

Genitalia. The epigynum is very small in E. nephiloides; in most other species it has a relatively long scape. The scape is attached to the anterior of the base and bends backward; in Verrucosa and in species previously considered to belong to Parawixia, it is attached ventrally. In $E$. ravilla and $E$. fuliginea the scape breaks off, probably in mating, and about half the females of these two species in collections lack the scape. It does not break off in the other two species, though $E$. edax may very rarely have the tip of the scape broken off. The base of the epigynum contains the seminal receptacles (SR in Figs. 5, 6). The shape of the seminal receptacles probably differs in different species, as reflected by the proportions of the base; this possibility was not pursued because the base is so 


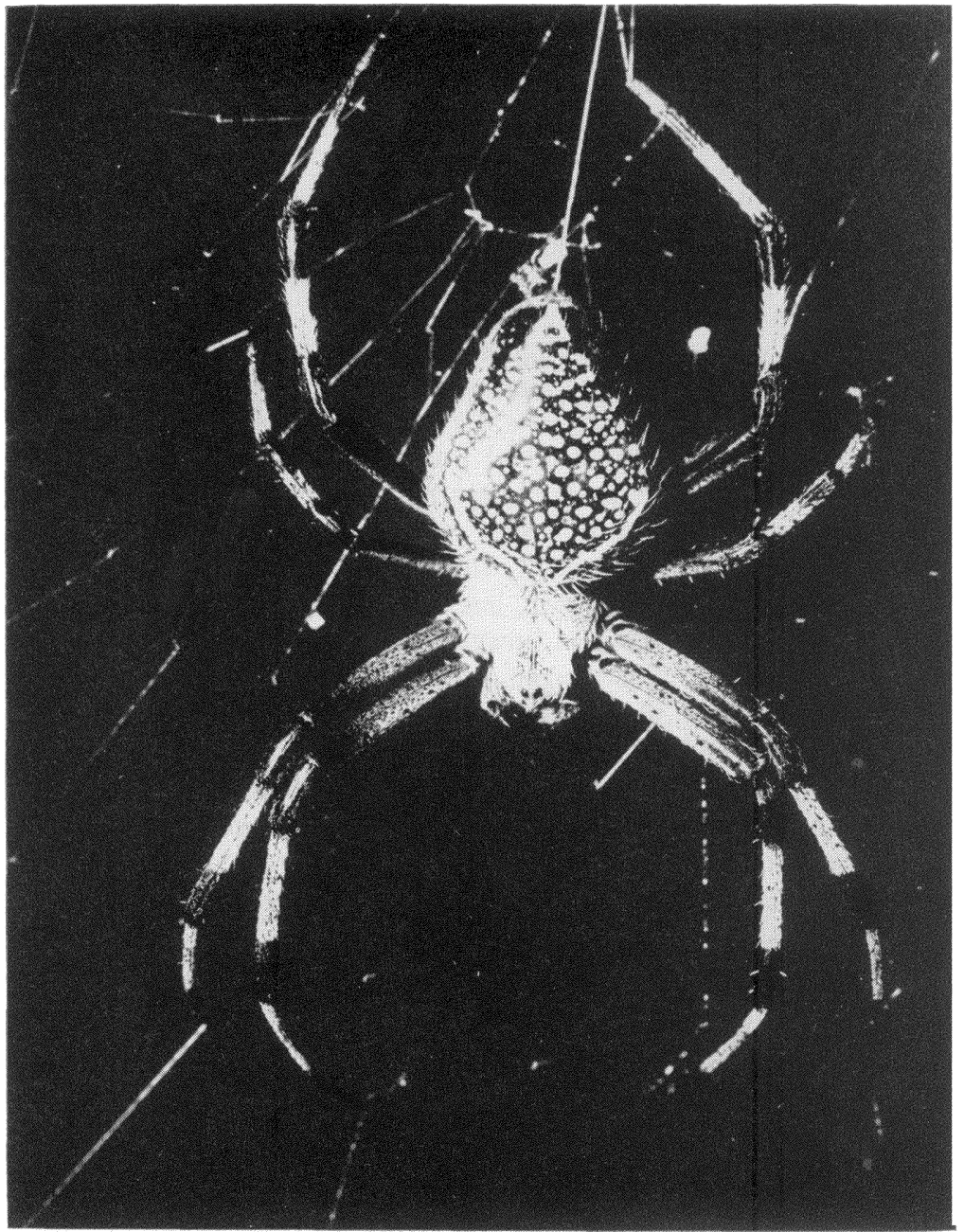

Fig. 1b. Eriophora nephiloides. Photograph taken at Barro Colorado Island, Panama Canal Zone by Dr. M. H. Robinson. 
heavily sclerotized that the character would be almost useless for separating species. The openings are ventral, under the scape (Fig. 5). The openings are bordered posteriorly by a triangular piece (Figs. 5, 14). There are no sclerotized basal lamellae as in some species of Araneus and Verrucosa.

The patella of the palpus has two macrosetae of which one may be much longer than the other.

The palpus of Eriophora was first described by Comstock (I9IO, 1912, 1940). In all species of Eriophora the palpus is similar in structure. The radix ( $R$ of Figs. 2-4), stipes (I) and median apophysis ( $\mathrm{M}$ ) are elongated compared to Araneus, but the tegulum (T) is compact (Figs. 2-4). As a result, the median apophysis has shifted laterally from the ventral position it occupies in Araneus, and if viewed from the mesal side seems to be behind the embolus ( $\mathrm{E}$ in Fig. 4). A separate piece, called the paramedian apophysis (PM) by Comstock, is present. In Verrucosa, which has a similar palpus, the piece is not separate, but is an extension of the proximal end of the conductor. Perhaps because parts of the bulb are elongated, the cymbium (Y) is very narrow and canoe-shaped. Unlike Araneus, Eriophora has little distal hematodocha $(\mathrm{DH})$ and the terminal apophysis (A) and embolus (E) are on a complex V-shaped structure that has only limited articulation with the stipes (I). A spur of the terminal apophysis is probably homologous to the subterminal apophysis of Araneus. If there is a tip that breaks off the embolus in mating, it must be small. None was seen, but emboli were not examined under a compound microscope.

Data from the collections indicate that throughout the range of the genus (except possibly the most northern parts), adult males can be found throughout the year and there is no definite season of maturity as in the species related to Araneus diadematus.

$W e b$. The web of E. fuliginea (according to M. H. Robinson, personal communication) has an open hub and usually is very asym-

Figs. 2-6. Structure of Eriophora genitalia, diagrammatic. 2-4. Left palpus. 2. Expanded, mesal. 3. Expanded, lateral. 4. Contracted, mesal. 5-6. Base of epigynum.

Figs. 7-9. Eriophora ravilla (C. L. Koch). 7. Male, fourth coxae and trochanters, ventral view. 8. Male, left second tibia and tarsus, ventral view. 9. Female, abdomen with epigynum, ventral view.

Abbreviations: A, terminal apophysis; C, conductor; D, sperm duct; DH, distal hematodocha; E, embolus; H, basal hematodocha; I, stipes; $M$, median apophysis; $P M$, paramedian apophysis; $P$, paracymbium; $R$, radix; S, subtegulum; SR, seminal receptacle; $T$, tegulum; $\mathrm{Y}$, cymbium.

Size Indicators: $1 \mathrm{~mm}$. 


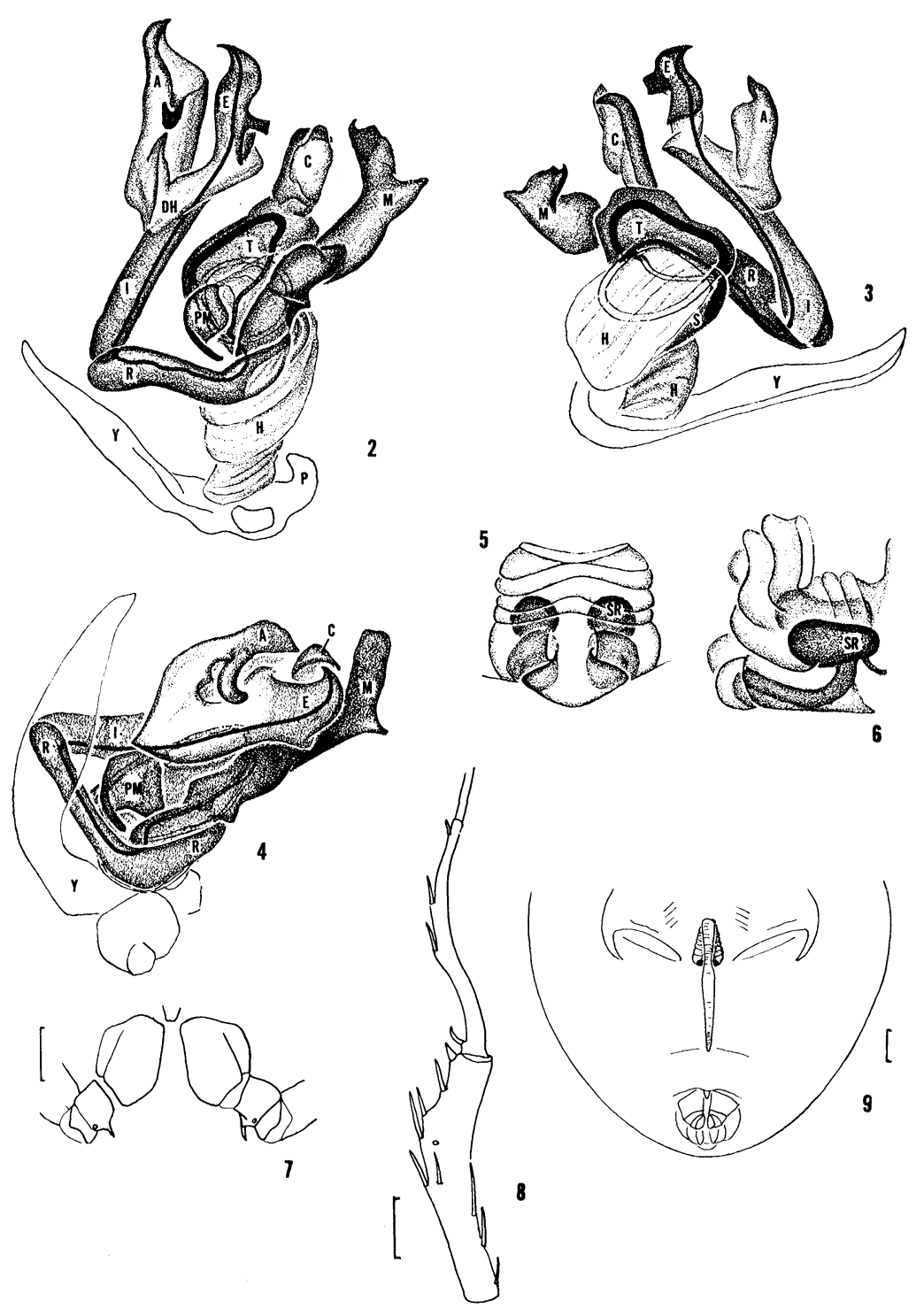


metrical. The hub is in the upper third of the web. The web may be as large as 1.6 to $2 \mathrm{~m}$ in diameter. The spider occupies a retreat to the side.

Distribution. There are specimens of Eriophora species in collections from New Guinea, New Caledonia, New Zealand and Australia. One species belonging to the genus has recently been described from South Africa.

Key to North American species of the ravilla group of Eriophora

Ia. Males 2

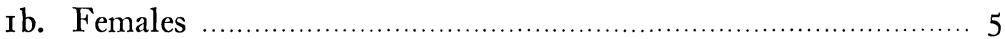

2a. Fourth coxa with a transverse row of 3 macrosetae (rarely, only 2 in northern specimens) (Fig. 48) .................... edax

2b. Fourth coxa without a transverse row of macrosetae (Figs. 7, 34)

3a. Median apophysis of palpus short, framed by other structures (Fig. 49) nephiloides

3b. Median apophysis of palpus long, extending beyond other structures (Figs. IO, 25, 35)

4a. Median apophysis with a spur (Figs. 2, IO); tip of embolus drawn out, recurved (Fig. II) ............................... ravilla

4b. Median apophysis without a spur (Fig. 25); tip of embolus with a flap on its side (Fig. 26) ........................... fuliginea

5a. Carapace, coxae yellow, sternum black; epigynum of minute size (Figs. 5 I, 54) nephiloides

5b. Coloration otherwise; epigynum of normal proportions ..... 6

6a. Posterior of dorsum of abdomen with a distinct hump (Fig. 42) ; scape of epigynum usually with a keel, sometimes circular in cross section, rarely broken off (Fig. 37) ……............. edax

6b. Posterior of dorsum with only a slight hump or none at all (Figs. 22-24); epigynal scope without a keel or often broken off (Figs. I 2, 27)

7a. Base of epigynum wrinkled (Fig. 13) 7

7b. Base of epigynum not wrinkled, but flat shield-shaped (Fig. 28)

fuliginea

$$
\begin{gathered}
\text { Eriophora ravilla (C. L. Koch) } \\
\text { Map I ; Figures 7-24 }
\end{gathered}
$$

? Epeira circulata Walckenaer, 1841, Histoire Naturelle des Insectes Aptères, vol. 3, p. 79. Female syntypes from America lost and also Abbot illustrations no. 170, 363 from Georgia. The Abbot manuscript is at the British Museum, Natural History. A copy of it in the Museum of Comparative Zoology was examined. Nomen dubium. 
Epeira ravilla C. L. Koch, 1845, Die Arachniden, vol. 11, p. 73, fig. 890, ․ Female holotype from Mexico in Royal Collection in Berlin, lost, likely destroyed. However, a specimen from Veracruz, Mexico, in the L. Koch collection in the British Museum, Natural History, with the label probably by C. L. Koch saying $E$. ravilla, examined. McCook, 1893, American Spiders, vol. 3, p. 161, pl. 5, figs. 7,8 , 우 $\hat{o}$.

? Epeira septima Hentz, 1847, J. Boston Soc. Natur. Hist., p. 470, pl. 30, fig. 9, + . The types from Alabama and North Carolina have been destroyed. Nomen dubium.

Eriophora ravilla, - Simon, 1864, Histoire Naturelle des Araignées, 1st ed., p. 261. F. P.-Cambridge, 1904, Biologia Centrali-Americana, Araneidea, vol. 2, p. 465. Roewer, 1942, Katalog der Araneae, vol. 1, p. 866. Bonnet, 1955, Bibliographia Araneorum, vol. 2, p. 1785.

Epeira nicaraguensis Keyserling, 1885, Verhandl. Zool. Bot. Ges. Wien, vol. 34, p. 523, pl. 13, fig. 31, ㅇ. Female holotype from Nicaragua in the Museum of Comparative Zoology, examined. Keyserling, 1893, Spinnen Amerikas, vol. 4, p. 214, pl. 10, fig. 159, + . NEW SYNONYMY.

Epeira balaustina McCook, 1888, Proc. Acad. Natur. Sci. Philadelphia, p. 198. Female syntypes from Florida, Swan Island, Caribbean, and San Domingo, lost; the type locality is here restricted to [tropical] Florida. McCook, 1893, American Spiders, vol. 3, p. 155, pl. 4, fig. 2, 우. NEW SYNONYMY.

Lipeira bivariolata O. P.-Cambridge, 1889, Biologia Centrali-Americana, Araneidea, vol. 1, p. 27, pl. 6, fig. 15, juv. Types from Guatemala in the British Museum, Natural History, lost. Nomen dubium. Keyserling, 1892, Spinnen Amerikas, vol. 4, p. 100, pl. 5, fig. 74, ô. McCook, 1893, American Spiders, vol. 3, p. 160 (in part), pl. 5, fig. 5, 우 $\hat{o}$.

Epeira variolata O. P.-Cambridge, 1889, Biologia Centrali-Americana, Araneidea, vol. 1, p. 46, pl. 6, fig. 14, juv. Juvenile syntypes from Guatemala in the British Museum, Natural History, lost.

Eriophora balaustina, - Banks, 1909, Rep. Centr. Exp. Sta. Cuba, p. 161, Epeira minax O. P.-Cambridge, 1893, Biologia Centrali-Americana, Araneidea, vol. 1, p. 112, pl. 15, fig. 1, o . Three female syntypes from Acaguizotla, Guerrero, Mexico, in the British Museum, Nautral History, examined. NEW SYNONYMY.

Eriophora minax, - F. P.-Cambridge, 1903, Biologia Centrali-Americana, Araneidea, vol. 2 , p. 464 , pl. 44, fig. 3 , ㅇ. Roewer, 1942, Katalog der Araneac, vol. 1, p. 867. Bonnet, 1955, Bibliographia Araneorum, vol. 2, p. 1784.

Aranea nicaraguensis, - F. P.-Cambridge, 1904, Biologia Centrali-Americana, Araneidea, vol. 2, p. 519. Roewer, 1942, Katalog der Araneae, vol. 2 , p. 848.

liriophora circulata, - Comstock, 1912, Spider Book, figs. 108-111, 538; 1940, Spider Book, rev. ed., figs. 108-111, 538. Probably not Eprira circulata Walckenaer.

? Araneus perfoliatus Franganillo, 1936, Los Aracnidos de Cuba, p. 70. Specimen in Cuban Academy of Sciences, Havana, with numbered code lacking key. Nomen dubium.

? Araneus anuncinatus Franganillo. 1963, Los Aracnidos de Cuba, p. 71. Specimen disposition, see above. Nomen dubium.

Araneus nicaraguensis, - Bonnet, 1955, Bibliographia Araneorum, vol. 2, p. 549. 


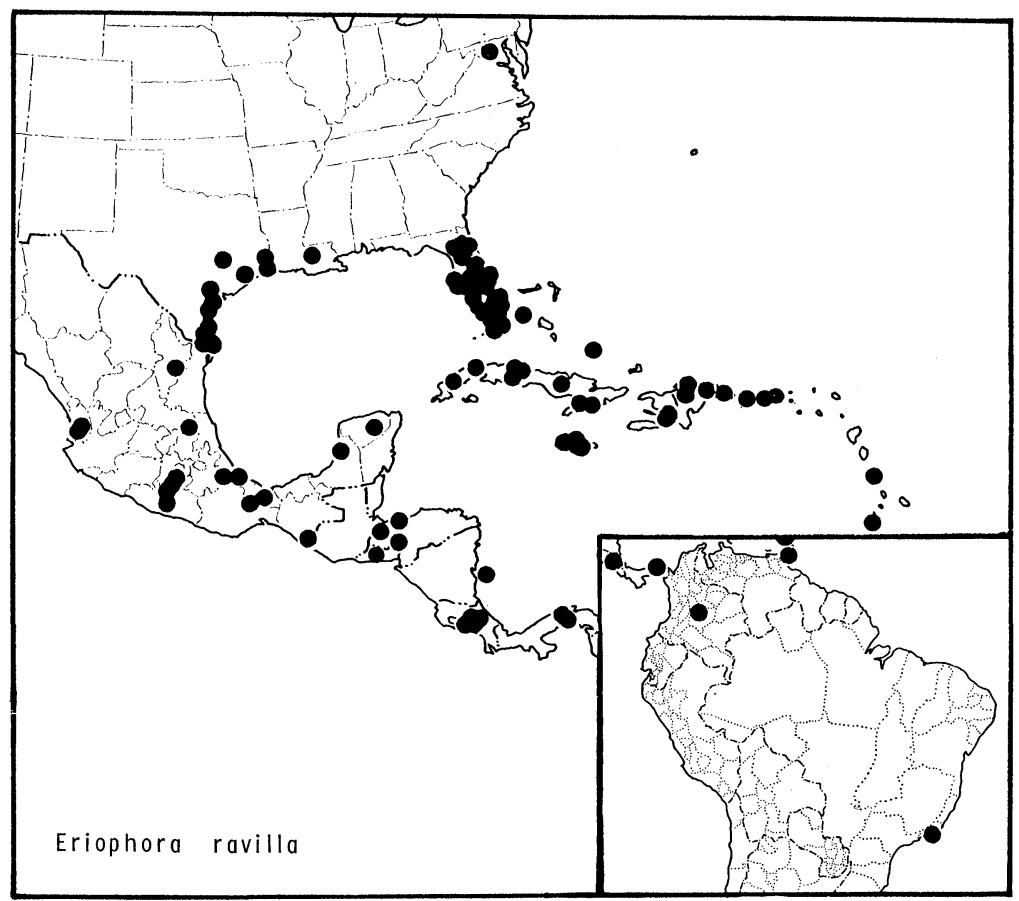

Map 1. Distribution of Eriophora ravilla (C. L. Koch)

Note. Walckenaer's ( $184 \mathrm{I}$ ) description of Epeira circulata suggests the pattern illustrated by Fig. 20, but the specimen is lost and Abbot's illustration, fig. I70 made from a Georgia spider, also resembles this pattern. However, this species is not usually found as far north as Georgia. Chamberlin and Ivie ( 1944, Bull. Univ. Utah, Biol. Ser., vol. 7, no. 5, p. IO5) interpreted the description to be an Eustala. Also I have not seen any other specimens with this pattern from the southeastern United States. It seems best not to use this doubtful name. The illustration of Epeira septima Hentz fits this species, the description may be a composite. Hentz reported the species from Alabama, where it occurs, and North Carolina, where it does not occur. Archer (1940) considered E. septima a synonym of Araneus trifolium.

In the L. Koch collection in London there are two specimens labeled $E$. ravilla, one from Cuba, and one from Veracruz, Mexico. Since the type locality is Mexico, I assume the Veracruz specimen 
might be the lost type, and that $\mathrm{L}$. Koch received the specimens from the elder Koch. The one from Cuba is Eriophora edax. McCook ( 1893) first suggested that balaustina might be ravilla of C. L. Koch.

Description. Female from Florida. Carapace red-brown with white hairs. Chelicerae dark brown. Sternum and coxae red-brown. Legs red-brown with femora darker and with white hairs and white setae. Dorsum of abdomen dark gray to black. Venter with a triangular black mark on gray with some white pigment surrounding it between epigynum and spinnerets. The triangular mark is pointed posteriorly. Anterior median eyes largest, posterior medians o.6 diameters of anterior medians, laterals radius of anterior medians. Anterior median eyes one diameter apart, posterior medians twothirds diameters apart. Abdomen is suboval, slightly pointed anteriorly and on sides. Total length $\mathrm{I} 7 \mathrm{~mm}$. Carapace $6.8 \mathrm{~mm}$ long, $5.8 \mathrm{~mm}$ wide. First femur, $7.6 \mathrm{~mm}$; patella and tibia, $9.6 \mathrm{~mm}$; metatarsus, $6.0 \mathrm{~mm}$; tarsus, $1.7 \mathrm{~mm}$. Second patella and tibia, 8.6 $\mathrm{mm}$; third, $4.7 \mathrm{~mm}$; fourth, $7.8 \mathrm{~mm}$.

Male from Cuba. Coloration almost like that of female. Legs banded. Abdomen dark gray. Carapace with a deep longitudinal thoracic groove. Eye proportions like those of female. The second tibia is illustrated in Fig. 8. Abdomen oval, widest anteriorly. Total length Io $\mathrm{mm}$. Carapace $5.3 \mathrm{~mm}$ long, $3.7 \mathrm{~mm}$ wide. First femur, $6.8 \mathrm{~mm}$; patella and tibia, $9.0 \mathrm{~mm}$; metatarsus, $6.3 \mathrm{~mm}$; tarsus, I. $4 \mathrm{~mm}$. Second patella and tibia, $6.8 \mathrm{~mm}$; third, $4.0 \mathrm{~mm}$; fourth, $5.8 \mathrm{~mm}$.

Variation. Females measure total length, I2-24 mm. Some females are almost white, others nearly black. Some have an irregular asymmetrical longitudinal white pigment patch which may be a narrow line or widest anteriorly just over the heart area. Males are $9-13 \mathrm{~mm}$ in total length. In some the legs lack banding. The abdomen is white to dark gray. Puzzling is the coloration (Fig. 20) having two dark-bordered, slightly sclerotized hunips, one after another. All but one with this coloration were juveniles, the only adult being from Veracruz, Mexico.

Diagnosis. Females are readily told from Eriophora fuliginea by the wrinkled base of the epigynum (Figs. 13-15), males by the spur on the median apophysis (Fig. Io).

Natural History. The species has been collected in live oak trees of scrub at a salt marsh in Levy County, Florida and on a hammock above dense undergrowth in Dade County, Florida. In Alachua 
County, Florida, H. K. Wallace (personal communication) observed a pompilid wasp [Poecilopompilus interruptus (Say)] attacking a spider while in the web and on the ground.

Distribution. Gulf coast, Florida, Central Mexico, and West Indies to South America.

Border records. Maryland. Bethesda, 6 August i943, $q$ (J. M. Davis. Grenada: near St. George's. Brazil. Rio de Janeiro, [I865-I 866], ơ (Thayer Exped.).

\section{Eriophora fuliginea (C. L. Koch), new combination \\ Map 2; Figures Ia, 25-34}

Epeira fuliginea C. L. Koch, 1893, Die Arachniden, vol. 5, pl. 58, fig. 375,

․ Three female syntype specimens from Brazil were in the Bavarian collection in Munich, presumably destroyed. - Taczanowski, 1873, Horae Soc. Entomol. Ross., vol. 9, p. 129.

Epeira hispida C. L. Koch, 1845, Die Arachniden, vol. 11, p. 71, fig. 889, ô. Male type from Brazil in the Zoologisches Museum, Humboldt Universität, Berlin; examined. NEW SYNONMY.

Epeira ursina Keyserling, 1865, Verhandl. Zool. Bot. Ges. Wien, vol. 15, p. 822, pl. 19, figs. 3-5, + . Female holotype from [the Spanish Colony] New Granada, in the British Museum, Natural History, examined. Keyserling, 1893, Spinnen Amerikas, vol. 4, p. 229, pl. 11, fig. 170, 우. NEW SYNONYMY.

Epeira trapezoides Karsch, 1879, Stettiner Entomol. Z. vol. 40, p. 107. Female holotype from Santa Marta, Colombia, in the Zoologisches Museum, Berlin, examined. NEW SYNONYMY

Epeira messalina Hasselt, 1888, Tijdschr. Entomol. 31: 181, pl. 6, figs. 1, 2, + Female holotype from Surinam, in the Natural History Museum, Leiden, examined. NEW SYNONYMY.

Epeira purpurascens O. P.-Cambridge, 1889, Biologia Centrali-Americana, vol. 1, p. 33, pl. 7, figs. 4, 5, + , $\hat{\delta}$. Female syntypes from Bugaba, Panama, in the British Museum (Natural History), examined. Keyserling, 1893, Spinnen Amerikas, vol. 4, p. 226, pl. 11, fig. 168, + , $\hat{o}$ [purpurescens]. NEW SYNONYMY.

Araneus fuligineus, - Simon, 1895, Histoire Naturelle des Araignées, vol. 1, p. 803. Bonnet, 1955, Bibliographia Araneorum, vol. 2, p. 505.

Araneus purpurascens, - Simon, 1897, Proc. Zool. Soc. London, p. 873.

Figs. 10-24. Eriophora ravilla (C. L. Koch). 10. Male, left palpus, mesal view. 11. Embolus. 12. Epigynum. 13-15. Base of epigynum. 13. Ventral. 14. Posterior. 15. Lateral. 16. Female, ventral view of abdomen. 17-21. Female, dorsal view of abdomen. 17. (Florida). 18. (Texas). 19. (Nayarit). 20. (Veracruz). 21. (Nicaragua). 22-24. Female, lateral view of abdomen. 22. (Jamaica). 23. (Nayarit). 24. (Veracruz).

Size Indicators: Figs. 10-15, $0.5 \mathrm{~mm}$. Figs. 17-24, $1 \mathrm{~mm}$. 

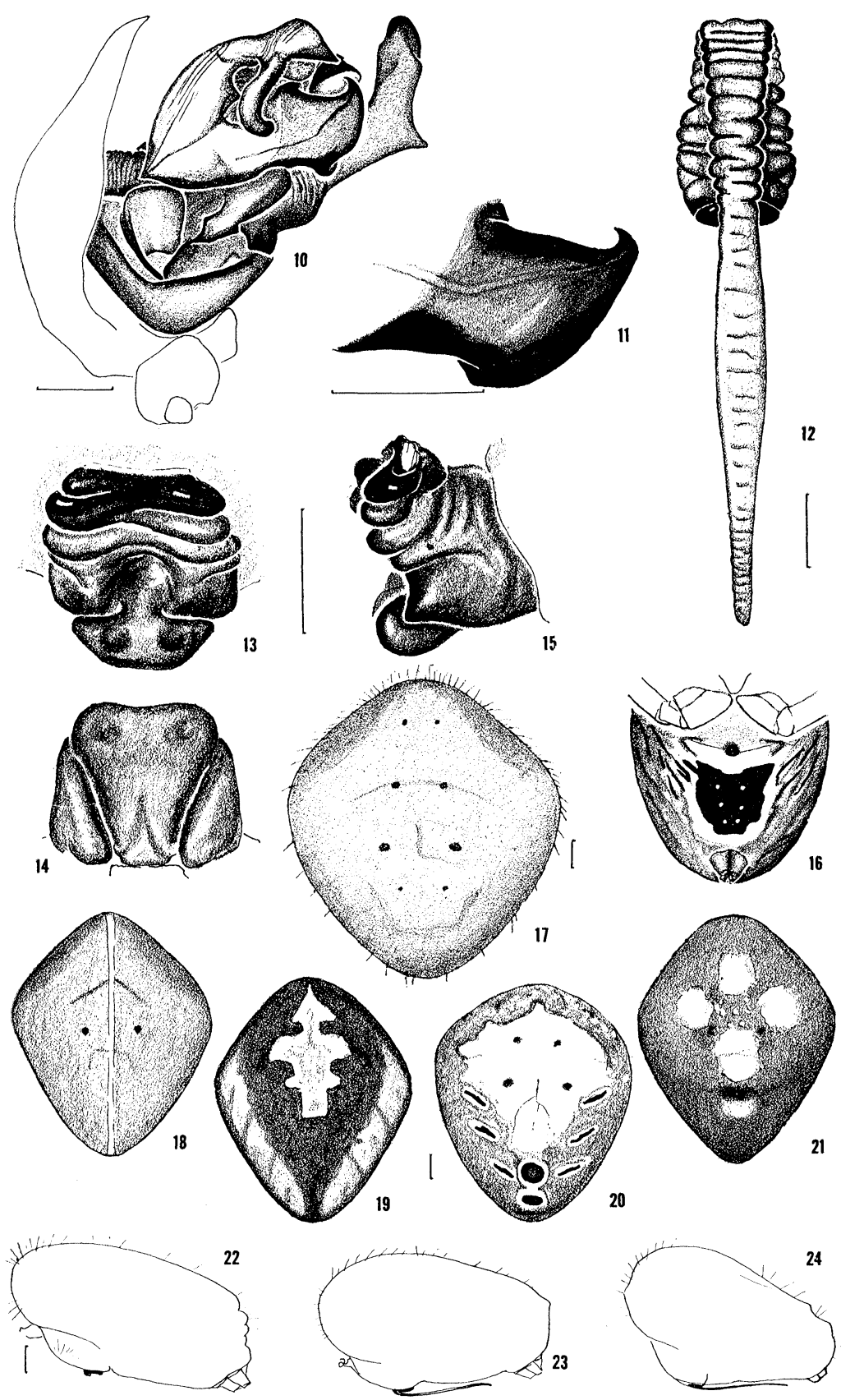


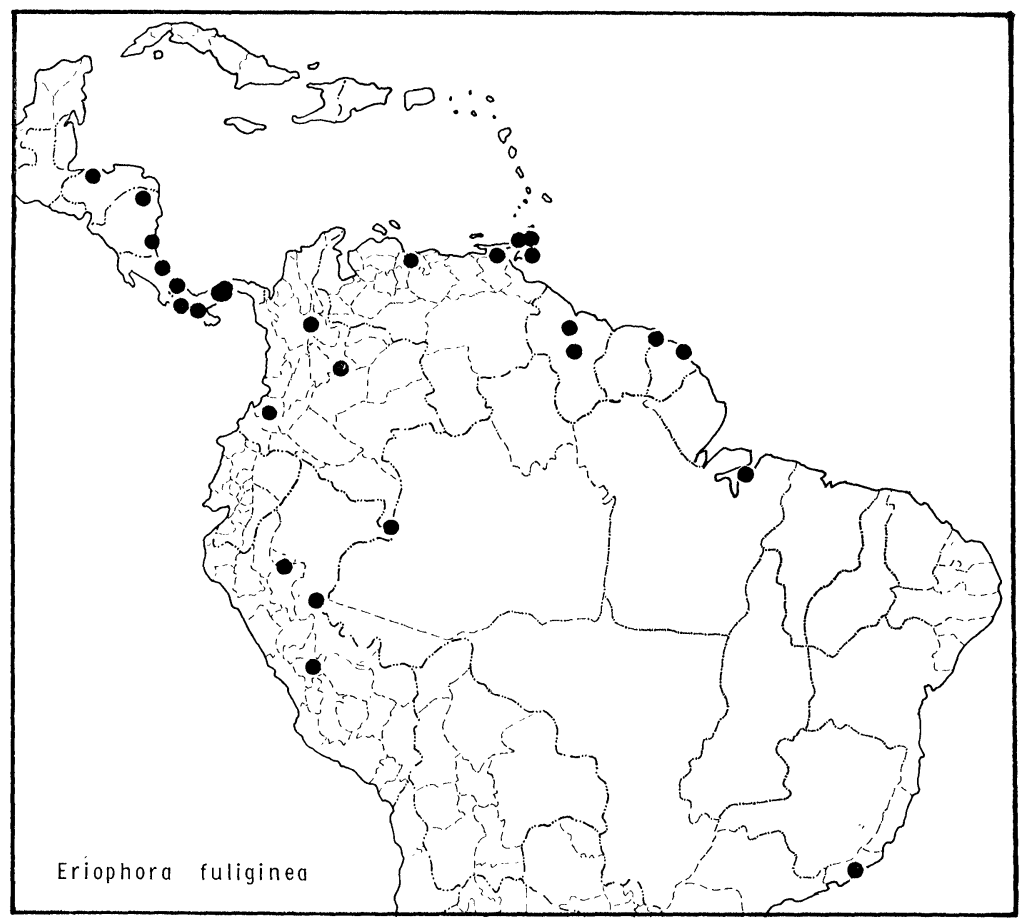

Map 2. Distribution of Eriophora fuliginea (C. L. Koch)

Eriophora purpurascens, - F. P.-Cambridge, 1903, Biologia Centrali-Americana, vol. 2, p. 463, pl. 43, figs. 14, 15, $ᄋ$, $\hat{o}$. Roewer, 1942, Katalog der Araneae, vol. 2, p. 867. Bonnet, 1955, Bibliographia Araneorum, vol. 2, p. 1784.

? Araneus fuligineus var. rhomboidalis Franganillo, 1936, Los Aracnidos de Cuba, p. 67. The Franganillo collection is in the Cuban Academy of Sciences, Havana, but with a numbered code and without a key to the numbers. Nomen dubium.

? Araneus fuligineus var. sanguineus Franganillo, 1936, Los Aracnidos de Cuba, p. 68. Specimen deposition, see above. Nomen dubium.

Aranea fuliginea, - Roewer, 1942, Katalog der Araneae, vol. 2, p. 842. Aranea ursina, - Roewer, 1942, Katalog der Araneae, vol. 2, p. 855.

Araneus ursinus, - Bonnet, 1955, Bibliographia Araneorum, vol. 2, p. 626.

Note. There are no specimens of Epeira fuliginea in the Staatsammlungen des Bayerischen Staates, Munich, according to Dr. Egon Popp. Presumably these were specimens collected by the Spix and Martius expedition to equatorial Brazil. The oldest specimens 

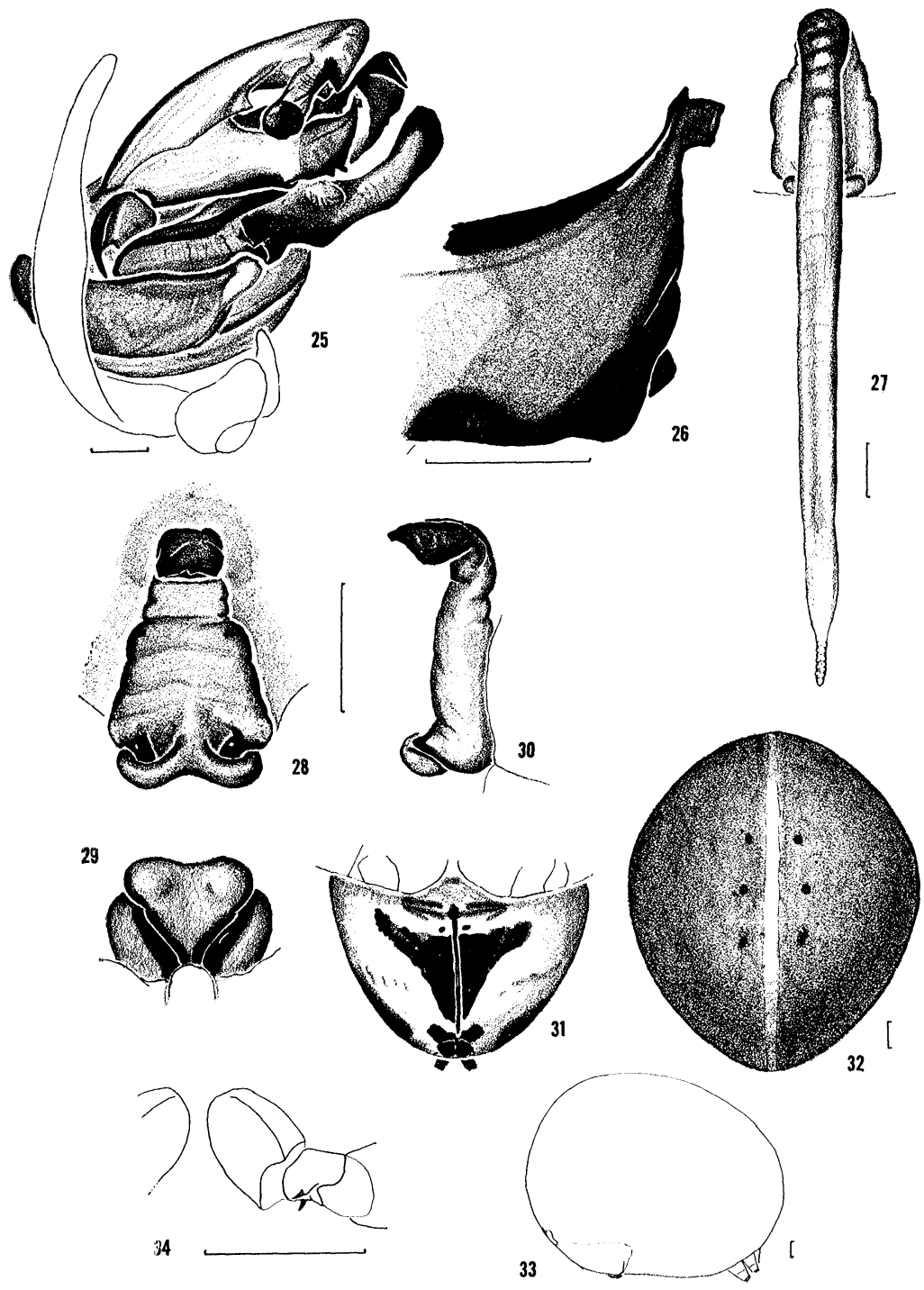

Figs. 25-34. Eriophora fuliginea (C. L. Koch). 25. Male, left palpus, mesal view. 26. Embolus. 27. Epigynum. 28-30. Base of epigynum. 28. Ventral. 29. Posterior. 30. Lateral. 31-33. Female, abdomen. 31. Ventral. 32. Dorsal. 33. Lateral. 34. Male, fourth coxa and trochanter.

Size Indicators: Figs. 25-30, $0.5 \mathrm{~mm}$. Figs. 31-34, $1 \mathrm{~mm}$. 
of this species examined bearing this name are those of Taczanowski in the Polish Academy of Sciences, Warsaw. The Franganillo names may refer to this species or $E$. ravilla.

Description. Female from Panama Canal Zone. Carapace, sternum, and legs brown. Carapace with some long white hairs from thoracic groove toward sides of head and shorter ones on the anterior margin. Dorsum of abdomen black with a well defined narrow longitudinal white line. Area on venter between epigynum and spinnerets with a triangular black mark pointing posteriorly, and a white pigment spot on each side anterior of the spinnerets (Fig. 3I). The dorsum of abdomen is sparsely covered by long white hairs. The anterior median eyes are largest, the posterior medians about 0.8 diameters of anterior medians, laterals about 0.7 diameters. The anterior median eyes are a little more than one diameter apart, the posterior medians about two-thirds diameters apart. The abdomen is subtriangular, rather high above spinnerets. Total length, $18 \mathrm{~mm}$. Carapace $8.3 \mathrm{~mm}$ long, $6.8 \mathrm{~mm}$ wide. First femur, Io.o mm; petella and tibia, I2.3 $\mathrm{mm}$; metatarsus, $8.7 \mathrm{~mm}$; tarsus, $2.6 \mathrm{~mm}$. Second patella and tibia, $12.4 \mathrm{~mm}$; third, $6.7 \mathrm{~mm}$; fourth, $10.5 \mathrm{~mm}$.

Male from Panama Canal Zone. Coloration like that of female but lighter. Sternum light brown. Distal segments of legs light with some dark spots at origin of setae. The carapace has a deep longitudinal thoracic groove with two short posteriorly directed branches. The anterior median eyes are largest, the posterior medians 0.7 diameters of anterior medians, the anterior laterals 0.6 diameters and the posterior laterals 0.5 diameters of anterior median eyes. The anterior median eyes are one and one-half diameters apart, the posterior medians about two-thirds their diameter apart. Total length, $14 \mathrm{~mm}$. Carapace $7.2 \mathrm{~mm}$ long, $6.0 \mathrm{~mm}$ wide. First femur, 8.0 $\mathrm{mm}$; patella and tibia, I0.5 $\mathrm{mm}$; metatarsus, $7.8 \mathrm{~mm}$; tarsus, $2.2 \mathrm{~mm}$. Second patella and tibia, $9.6 \mathrm{~mm}$; third, $5.5 \mathrm{~mm}$; fourth, $8.0 \mathrm{~mm}$.

Variation. The total length of the female varies between $14-30$ $\mathrm{mm}$. The total length of adult males $12-16 \mathrm{~mm}$. The largest come from the northern Amazon region. The dorsal white line on the abdomen may be absent. The dorsum sometimes has white patches instead of a line and sometimes the sides of the abdomen have white pigment patches. Most specimens, however, do have the longitudinal line. Some females have a dorsal posterior hump on the abdomen as large as that of E. edax. The length of the scape of the epigynum 


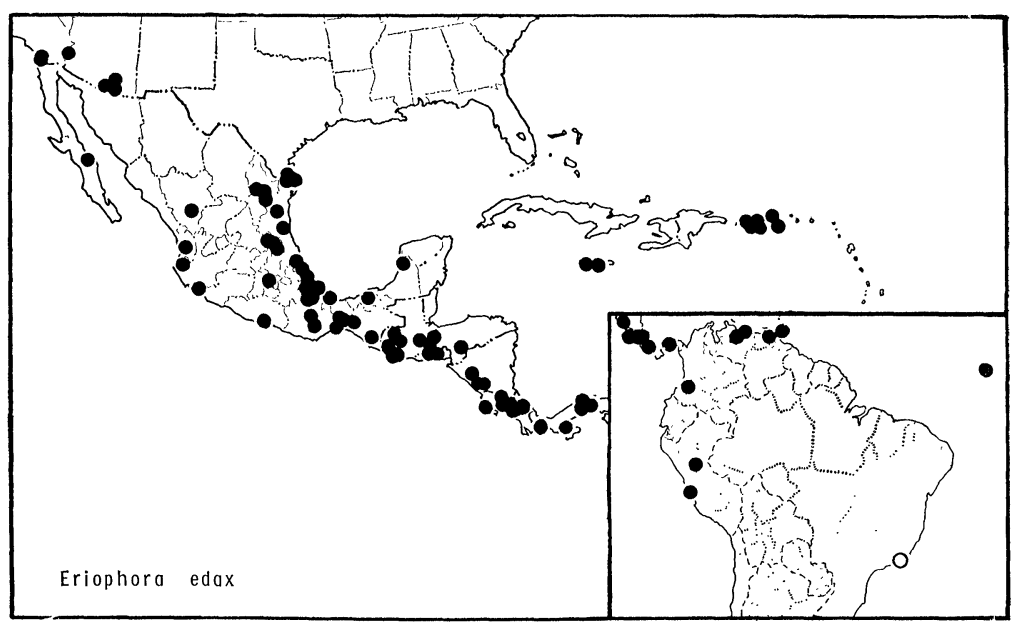

Map 3. Distribution of Eriophora edax (Blackwall)

seems quite variable. Sometimes it extends as far as the anterior spinnerets, sometimes it is shorter, depending perhaps on the size of the abdomen. One male from Panama had a hump as well as two macrosetae on the posterior edge of the fourth coxae. (All Panamanian $E$. edax had three or four macrosetae.)

Diagnosis. This species differs from Eriophora ravilla, the epigynum of which also has a flat scape, by the shield-shaped base of the epigynum (Figs. 28-30). In Eriophora ravilla the base of the epigynum has annuli, in Eriophora fuliginea it does not. The median apophysis (Fig. 25) of the male differs in lacking the spur present in Eriophora ravilla. The distal edge of the median apophysis has a flat edge and the shape of the embolus with a flap near the tip is characteristic (Fig. 26).

Natural History. The spider is known to be nocturnal and has been observed occasionally to feed on bats, probably Myotis nigricans, that become entangled in the large web (Fig. Ia) (personal communication of $M$. H. Robinson).

Distribution. Honduras, Trinidad to western Peru and southeastern Brazil (Map 2).

Border Records. Honduras: Tela. Peru. Junín: Amable María (K. Jelski). Brazil. Rio de Janeiro. 


\section{Eriophora edax (Blackwall) \\ Map 3; Figures 35-48}

Epeira edax Blackwall, 1863, Ann. Mag. Natur. Hist. ser. 3, vol. 11, p. 30. Female and male syntypes from Rio de Janeiro, Brazil, lost, probably destroyed.

Eriophora edax, - F. P.-Cambridge, 1903, Biologia Centrali-Americana, Araneidea, vol. 2, p. 464, pl. 44, figs. 1, 2, ㅇ, $\hat{o}$. Petrunkevitch, 1930, Trans. Connecticut Acad. Sci., vol. 30, p. 325, figs. 205-207, 우 $\hat{o}$.

Aranea edax cauca Strand, 1915, Arch. Naturgesch., vol. 81, p. 111. Juvenile holotype from Popayan or Cauca, Colombia in the Senckenberg Museum, Frankfurt, examined. NEW SYNONYMY.

Note. Blackwall's rather detailed description matches specimens of this species. The unusual macrosetae in a line across the fourth coxa of males are mentioned by Blackwall. The proportions given by Blackwall fit. The Blackwall types are not known to exist. There are no recent collections of this species from Rio de Janeiro (open circle Map 3) but there are some from the east side of the Andes in the Amazon basin in Peru. Thus the recognition of the Blackwall name is not in doubt. Strand's specimen is a characteristic specimen, a juvenile, of this species.

Description. Female from Arizona. Carapace yellow-brown with a median longitudinal dark brown band and irregular brown spots. Clypeus dark brown, as is median eye area not including the posterior median eyes but including the anterior lateral eyes. Labium and endites dark brown, distally white. Sternum marbled brown. Coxae brown, bordered by dark brown. Legs banded with narrow bands, more distinct on venter. Abdomen with black and white pigment on dorsum (Figs. 4I-47). Venter with a black mark wider than long, surrounded by white. Spinnerets dark brown. Anterior median eyes largest, posterior medians the radius of anterior medians in size, anterior laterals 0.8 diameters of anterior medians, posterior lateral eyes the radius of anterior medians. Anterior median eyes less than one diameter apart, posterior median eyes a little more than one diameter apart. The abdomen has a median dorsal hump and a smaller hump anteriorly. Total length $\mathrm{r} 4 \mathrm{~mm}$. Carapace $6.2 \mathrm{~mm}$

Figs. 35-48. Eriophora edax (Blackwall). 35. Male, left palpus, mesal view. 36. Embolus. 37. Epigynum. 38-40. Base of epigynum. 38. Ventral. 39. Pusterior. 40. Lateral. 41-47. Female, abdomen. 41. Ventral. 42-44. Dorsal view. 42. (Arizona). 43. (Veracruz). 44. (Loreto, Peru). 45-47. Lateral view. 45. (Arizona). 46. (Puerto Rico). 47. (Veracruz). 48. Male, fourth coxae and trochanters.

Size Indicators: Figs. $35-40,0.5 \mathrm{~mm}$. Figs. $41-47,1 \mathrm{~mm}$. 


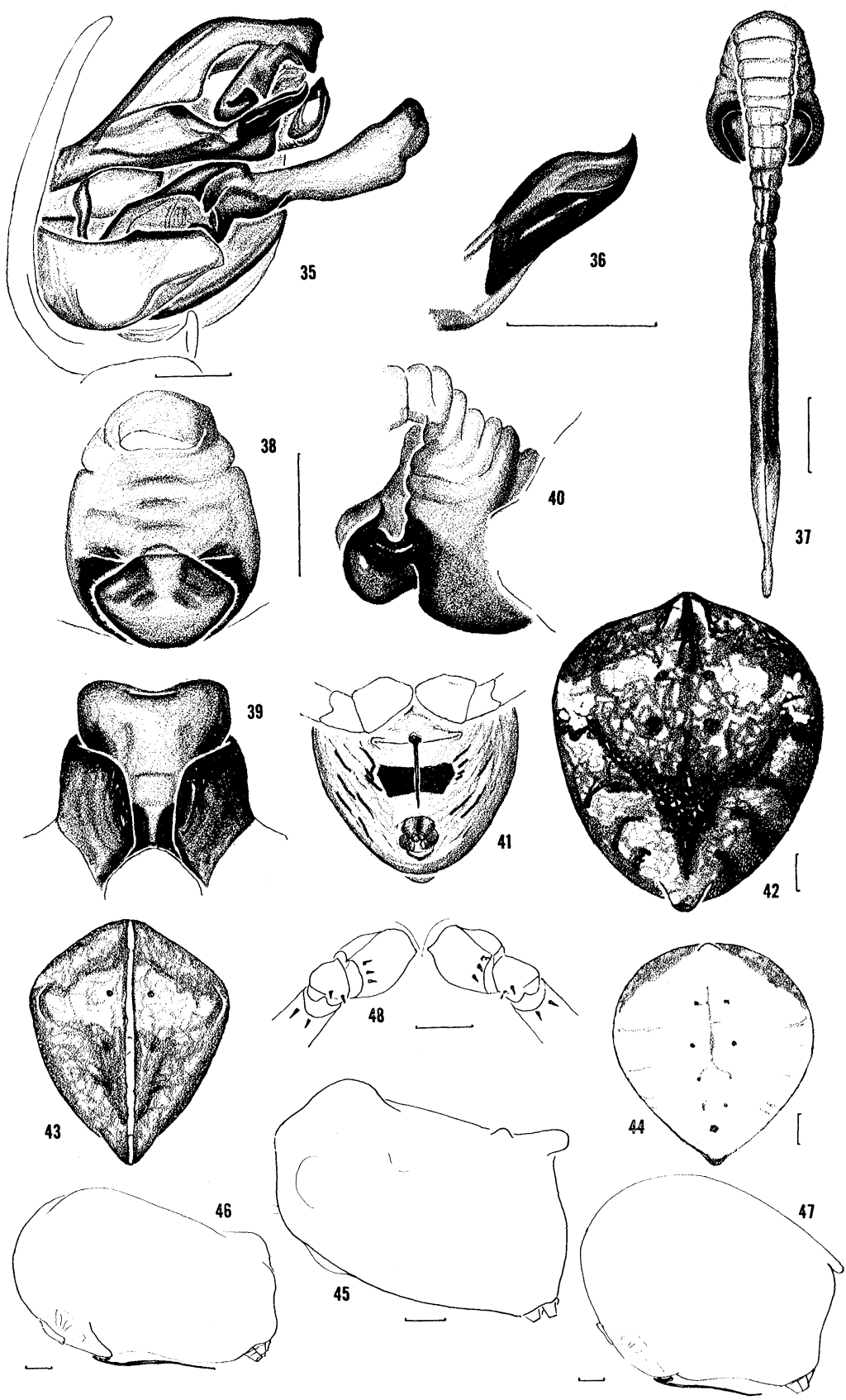


long, $5.0 \mathrm{~mm}$ wide. First femur, $5.8 \mathrm{~mm}$; patella and tibia, $8.0 \mathrm{~mm}$; metatarsus, $4.7 \mathrm{~mm}$; tarsus, $1.6 \mathrm{~mm}$. Second patella and tibia, 6.9 $\mathrm{mm}$; third, $4.0 \mathrm{~mm}$; fourth, $6.5 \mathrm{~mm}$.

Male from Arizona. Carapace and sternum light brown. Legs only indistinctly banded. Dorsum of abdomen evenly covered with white pigment and tiny black spots at the base of setae. Venter with area between genital groove and epigynum white. Carapace with a deep longitudinal groove. Eye sizes almost like those of female. Anterior median eyes slightly more than their diameter apart, posterior median eyes slightly more than their diameter apart. Abdomen subtriangular with a distinct posterior hump. Total length i I $\mathrm{mm}$. Carapace $5.8 \mathrm{~mm}$ long, $4.4 \mathrm{~mm}$ wide. First femur, $5.8 \mathrm{~mm}$; patella and tibia, $7.2 \mathrm{~mm}$; metatarsus, $4.7 \mathrm{~mm}$; tarsus, $1.4 \mathrm{~mm}$. Second patella and tibia, $6.4 \mathrm{~mm}$; third, $3.6 \mathrm{~mm}$; fourth, $5.4 \mathrm{~mm}$.

Variation. Some specimens have the cephalothorax red-brown and abdomen almost black; other have the cephalothorax yellowish-brown and the abdomen white or yellow-brown. The abdomen may have a folium-like patch (Fig. 42) or may be almost completely white as in a specimen from Peru (Fig. 44). The posterior dorsal hump is distinct in all specimens. But there may be two posterior humps in a row and other humps. The keel of the epigynum scape is less distinct in some specimens from Central and South America but the shape of the base of the epigynum stays about the same. No specimens were seen in which the scape was torn off, but in some the tip had broken off. Northern males, from Mexico and the United States, may have only two macrosetae on the fourth coxa while those examined from Central and South America all had three or four macrosetae. Females ranged from $12-16 \mathrm{~mm}$ in total length, males from 8-12 $\mathrm{mm}$ in total length.

Diagnosis. The keel of the epigynal scape (Fig. 37), the large projecting median sclerite of the base of the epigynum (Figs. 38-40), and the cylindrical embolus of the male palp (Fig. 36) and usually the macrosetae across coxa (Fig. 48) and the large posterior hump of the abdomen (Figs. 45-47) can be used to separate specimens of E. edax from those of E. fuliginea.

Distribution. From southern Texas, Arizona and southern California to Peru and Brazil (Map 3).

$$
\begin{gathered}
\text { Eriophora nephiloides (O. P.-Cambridge) } \\
\text { Map 4; Figures Ib, 49-58 }
\end{gathered}
$$

Epeira nephiloides O. P.-Cambridge, 1889, Biologia Centrali-Americana, Araneidea, vol. 1, p. 32, pl. 7, figs. 1, 2, ․ Female syntypes from Panzos, 


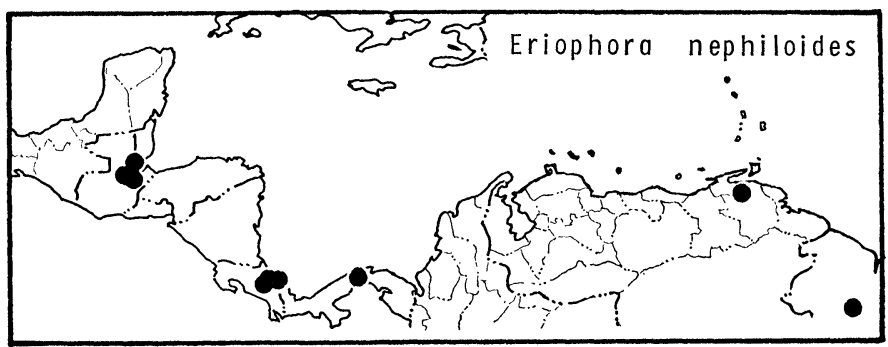

Map 4. Distribution of Eriophora nephiloides (O. P.-Cambridge)

Dolores, Cubilguitz and [?] Menché, Guatemala in British Museum, Natural History, examined.

Araneus nephiloides, - Simon, 1895, Histoire Naturelle des Araignées, vol. 1, p. 811.

Aranea nephiloides, - F. P.-Cambridge, 1904, Biologia Centrali-Americana, Araneidea, vol. 2, p. 511, pl. 48, fig. 22, 오 .

Eriophora nephiloides, - Banks, 1909, Proc. Acad. Natur. Sci. Philadelphia, p. 210. Roewer, 1942, Katalog der Araneae, vol. 1, p. 867. Bonnet, 1955, Bibliographia Araneorum, vol. 2, p. 1784.

Description. Female from Panama Canal Zone. Carapace yellowish-white, dusky in the center and including head region. Sternum dark brown. Coxae yellow-white. Legs yellow-white, banded brown. Dorsum of abdomen white, sides yellow-white with a black edge toward dorsal white spot. Venter of abdomen with a black rectangle longer than wide, bordered by white. The pigment covers almost the entire area between epigynum and spinnerets. Anterior median eyes slightly larger than others, posterior medians 0.9 diameters of anteriors, laterals about 0.8 diameters of anterior medians. Anterior medians one and one-half diameters apart, posterior medians more than one diameter apart. Abdomen longer than wide, widest in anterior half, sometimes pear-shaped, quite variable. Total length, I6 mm. Carapace 6. I mm long, $5.2 \mathrm{~mm}$ wide. First femur, $8.9 \mathrm{~mm}$; patella and tibia, $10.5 \mathrm{~mm}$; metatarsus, $8.2 \mathrm{~mm}$; tarsus, $2.3 \mathrm{~mm}$. Second patella and tibia, I0.0 $\mathrm{mm}$; third, $5.3 \mathrm{~mm}$; fourth, $8.6 \mathrm{~mm}$.

Male from Panama Canal Zone. Carapace darker than that of female. Sternum with dark border only. Legs are not banded. Dorsum of abdomen all white, ventral abdominal black band may be wider than long or as wide as long. Anterior median eyes largest, posterior medians about 0.8 diameters of anterior medians, laterals about the radius of anterior medians. Anterior median eyes slightly more than one diameter apart, posterior medians slightly more than 
one diameter apart. Coxae not modified. Second tibia is thick but not otherwise modified. The abdomen is longer than wide, widest in anterior half and has long hair. Total length $5 \mathrm{~mm}$. Carapace $2.5 \mathrm{~mm}$ long, $2.3 \mathrm{~mm}$ wide. First femur, $2.9 \mathrm{~mm}$; patella and tibia, $3.8 \mathrm{~mm}$; metatarsus, $2.5 \mathrm{~mm}$; tarsus, $0.8 \mathrm{~mm}$. Second patella and tibia, $3.3 \mathrm{~mm}$; third, r. $6 \mathrm{~mm}$; fourth, $2.6 \mathrm{~mm}$.

Variation. The female varies from I I-22 $\mathrm{mm}$ total length. The abdomen may be quite variable in markings and color (Figs. 55, 56) and also the white dorsal patch is variable in shape. In some specimens the white patch appears spotted.

Diagnosis. The short median apophysis (Fig. 49) and the striking coloration of the female and small epigynum (Figs. 5I-54) with unsclerotized scape separates this species from others. This species appears to be close to Epeira musiva (Hasselt) but differs by the epigynum.

Natural History. According to M. E. Robinson (personal communication), this species unlike $E$. fuliginea is mainly diurnal. The carapace in the living animal is brilliant emerald green.

Distribution. Guatemala to Guiana (Map 4).

Records. Guatemala (syntypes). Costa Rica. Limón, Río Toro Amarillo; Calle Angeles, $5 \mathrm{~km} \mathrm{S.} \mathrm{de} \mathrm{Univ.;} \mathrm{Guápiles.} \mathrm{Panama}$ Canal Zone. Barro Colorado Isl. Venezuela. Caripito. Guiana. Tukeit [Falls], r9i I (Lza.).

\section{References Cited}

Archer, A. F.

1940. Paper Alabama Mus. Natur. Hist., 14: 1-77.

BonNeT, P.

1955. Bibliographia Araneorum, 2, part 2. Toulouse.

Figs. 49-58. Eriophora nephiloides (O. P.-Cambridge), 49. Male, left palpus, mesal view. 50. Embolus. 51-53. Epigynum. 51, 52. Ventral. 51. (Syntype, Guatemala). 52. (Panama Canal Zone). 53. Posterior view (syntype, Guatemala). 54-55. Female, abdomen. 54. Ventral view. 55. Dorsal view (Panama). 56. Female, dorsal view, appendages removed (Panama). 57. Female, abdomen, lateral view. 58. Male, fourth coxa and trochanter.

Size Indicators: Figs. 49, 51-53, $0.5 \mathrm{~mm}$. Fig. 50, $0.05 \mathrm{~mm}$. Figs. 54-57, $1 \mathrm{~mm}$. 


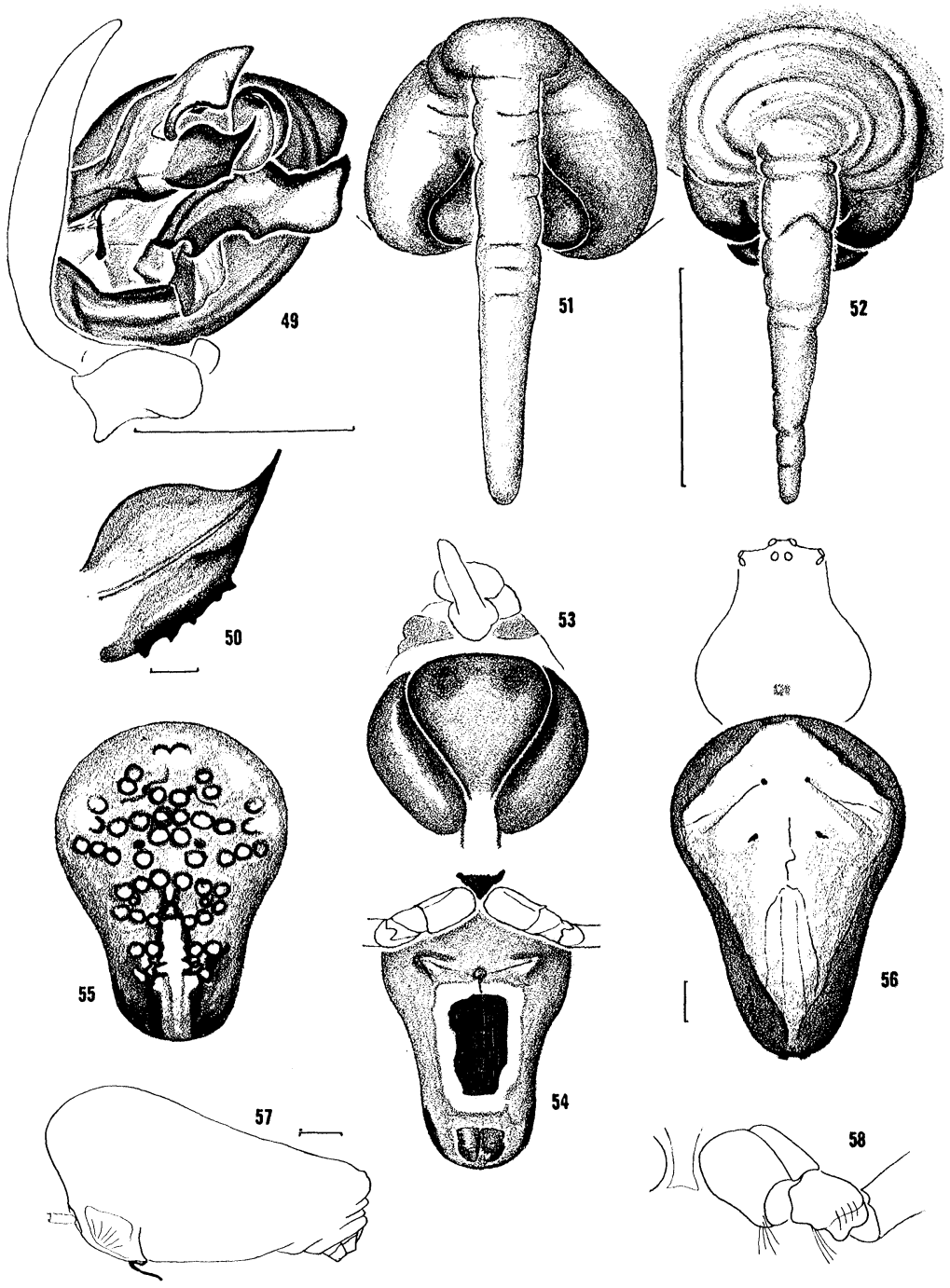


Comstock, J.

1910. The palpi of male spiders. Ann. Entomol. Soc. Amer., 3: 161-185.

1912. The Spider Book. Garden City, New York.

1940. The Spider Book, rev. ed. Garden City, New York.

KEYSERLING, E.

1892-1893. Die Spinnen Amerikas, 4, publ. by G. Marx. Nürnberg.

McCooK, H. C.

1894. American Spiders and their Spinning Work, 3. Philadelphia.

ROEWER, C. F.

1942. Katalog der Araneae, 1. Hamburg.

Chamberlin, R. V. and W. Ivie

1944. Spiders of the Georgia Region of North America. Bull. Univ.

Utah, Biol. Ser. 8(5): 1-267. 

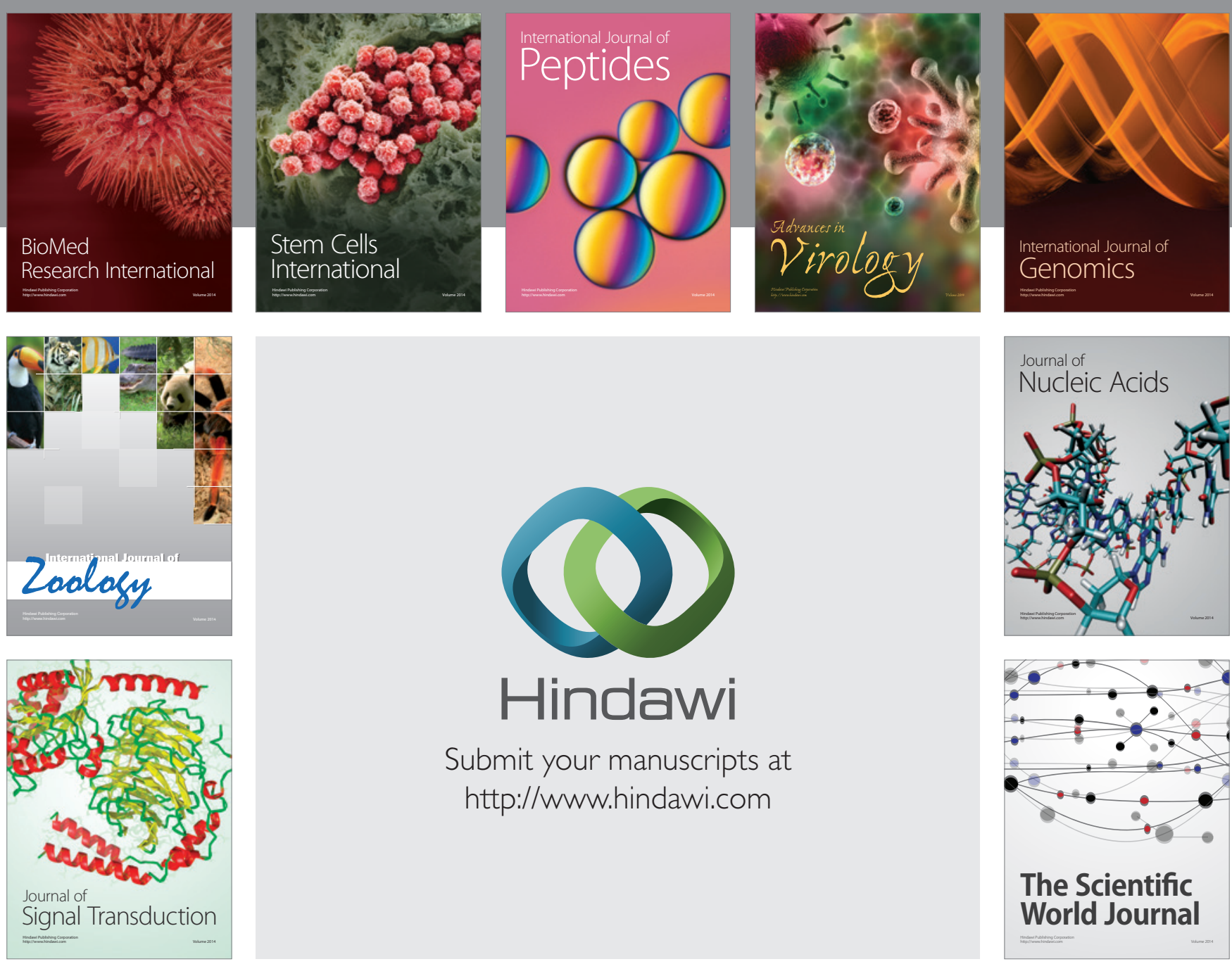

Submit your manuscripts at

http://www.hindawi.com
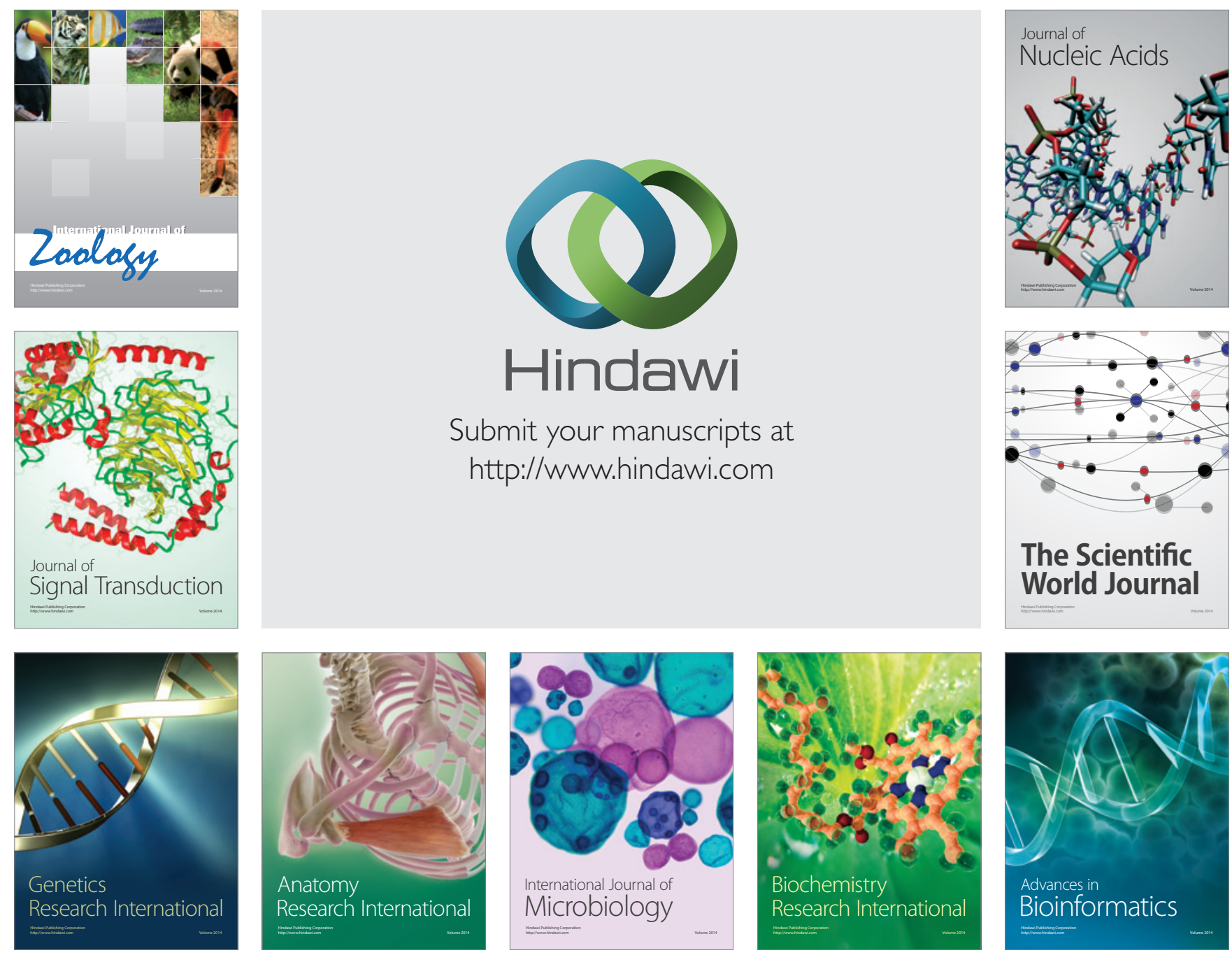

The Scientific World Journal
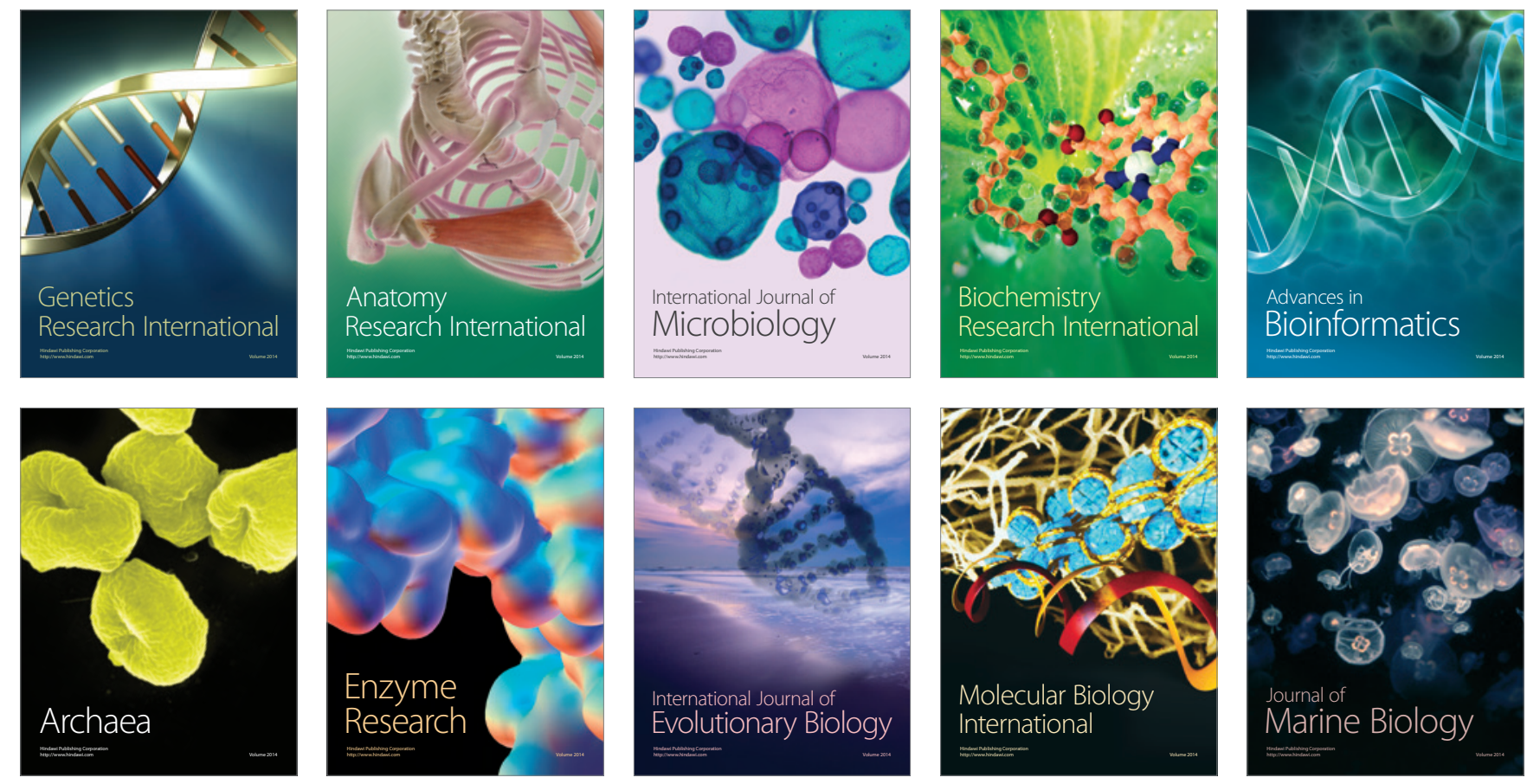